\title{
The Countermeasure Research on The Ideological and Political Leading Work of the Communist Youth League in Colleges and Universities In The New Era
}

\author{
Chunming $\mathrm{Xu}^{1}$, Can Wang ${ }^{2,}$, Nan Yang ${ }^{3}$ \\ ${ }^{1}$ Student Development and Services Office, Dalian University of Science and Technology, Dalian, Liaoning 116052, \\ China \\ ${ }^{2}$ School of Digital Technology, Dalian University of Science and Technology, Dalian, Liaoning 116052, China \\ ${ }^{3}$ School of Economics and Management, Dalian University of Science and Technology, Dalian, Liaoning 116052, China \\ *Corresponding author. Email: 652196979@qq.com
}

\begin{abstract} realize the transformation of ideological and political job.

\section{THE IDEOLOGICAL AND POLITICAL LEADING DISCOURSE OF THE COMMUNIST YOUTH LEAGUE IN COLLEGES AND UNIVERSITIES}

Under the new situation, the CPC central committee and the youth league central committee have put forward new requirements and instructions on the ideological and political work of the youth league in colleges and universities. Ideological and political guidance of the communist youth league in colleges and universities should work in depth for ideological and political task in colleges and the pattern of "Big Ideological And Political". This article clarifies the changes of the arteries and veins, the communist youth league of ideological and political leading discourse. This article analyzes the plight of the communist youth league of ideological and political lead, and emphatically from the young students spiritual growth needs, " The Young Marxist Project " training carrier fundamental duties, close relationship between the new media and the young students, young students of different levels demand four aspects to carry on the thinking and research, so as to

Keywords: Universities, communist youth league, ideological and political, leading countermeasures

Combing and explaining the concepts is the basic principle of theoretical research, so is the concept of "ideological and political guidance of the communist youth league in colleges and universities". Some scholars put forward that "the ideological guidance of the communist youth league of colleges and universities" includes three meanings: first, the communist youth league of colleges and universities follows closely the pace of the party committee of the university and the organization of the communist youth league of higher levels, explores the characteristics and rules of the ideological growth of young students in colleges and universities, and carries out work according to the rules; the second is the communist youth league in colleges and universities closely around the basic task of college 'foster virtue through education', give full play to the group's resources and advantages, to college students thought, further enhance the college students for the road of socialism with Chinese characteristics confidence, theory and system, for now the great revival of the Chinese dream youth, wisdom and power; third, the essence of ideological guidance of the communist youth league in colleges and universities is to promote the youthfulness of Marxism.

\section{THE DILEMMA FACED BY THE IDEOLOGICAL AND POLITICAL GUIDANCE WORK OF THE COMMUNIST YOUTH LEAGUE IN COLLEGES AND UNIVERSITIES}

\subsection{Path of Guidance: Solidified Mode of Ideological and Political Guidance}

\begin{abstract}
There are some phenomena such as weak ideals and beliefs, weak pioneer consciousness, and weak organizational concept among contemporary college students. There are some problems in the youth league organizations of colleges and universities, such as single methods to solve problems and inadequate measures. Due to the lack of investigation and evaluation on the spiritual growth needs of young college students, the ideological and political education in colleges and universities mostly adopts the form of holding lectures, league day activities or themed educational activities, resulting in the lack of appeal and appeal of educational practice. Therefore, the ideological and political leading work should focus on the growth needs of young students, impress young people with simple and easy to understand content, attract young people with popular and fashionable ways, infect young people with good people and good things around, and give full play to the comparative advantages of the ideological
\end{abstract}


and political leading work of the communist youth league in guiding young students.

\subsection{Leading Platform: The Training Mechanism of "The Young Marxist Project" Needs to Be Improved}

In recent years, various colleges and universities have effectively carried out the "The Young Marxist Project" series of work. Although some achievements have been made, there are still some problems, mainly manifested in the following aspects:

First, the core task is not clear. The core task of " The Young Marxist Project" is to strengthen the ideals and beliefs of the training objects. However, many colleges and universities pay too much attention to the comprehensive ability and quality of students' work and practical training in the actual training process, without considering the relationship between the general training and the key training, and neglect the core training objectives.

Second, the training courses are not perfect. The teaching and management outline of the backbone training school for Chinese college students puts forward a preliminary management system for the courses and credits of " The Young Marxist Project", but the practical experience and problem orientation of the outline belong to the top-level design, and the specific planning and design still need the youth league committee of colleges and universities to carry out more detailed scientific planning according to their own characteristics [1]. At present, the urgent problem for the youth league organizations in colleges and universities is how to scientifically and rationally design the course content system of " The Young Marxist Project", which is different from ideological and political theory teaching, according to the core training objectives and the development characteristics and needs of the young political backbone, and compile and print the training materials that are closely combined with the characteristics of students and the university situation within a limited period of time.

Third, lack of job security. The" The Young Marxist Project" initiated and implemented by the communist youth league mainly trains people to be the backbone of the league. Other departments in the university seldom participate in the project, so the training scope has some limitations. The implementation of " The Young Marxist Project" requires relatively fixed training teachers, training materials, training funds and training platforms, etc. After the whole training project has gradually entered a period of stable development, it will be inadequate to rely on the communist youth league to organize and implement the project, and the resources needed by all parties will not be fully guaranteed[2].

\subsection{Level of Guidance: The "Precise Supply" Of Ideological and Political Guidance Needs to Be Strengthened}

At present, the communist youth league of colleges and universities often pursues full coverage of the ideological guidance of young students, ignoring the individualized teaching for different groups, resulting in the unification of ideological education contents and methods and unsatisfactory guidance effect. For example, different stages of students' growth have different characteristics, and undergraduates and postgraduates in different stages face different campus life and study. At the same time, individual students also have differences, have good learning, poor learning, outgoing, conservative personality, have good economic conditions, economic difficulties. Therefore, the ideological and political education of college students should pay attention to the detailed classification, clear positioning, and follow the objective law of the growth and development of young students, so as to build a hierarchical classification integrated working mechanism system and further improve the ideological investigation mechanism of students. It is necessary to conduct an online and offline survey and comprehensive analysis of students' ideological dynamics from the perspective of practical investigation, so as to provide effective guidance.

\subsection{Leading Carrier: The Double-sided Influence of New Media On the Spiritual Life of Young Students}

The new network media not only enriches the way for the ideological guidance of the communist youth league of colleges and universities, but also brings some challenges to the ideological guidance of the communist youth league of colleges and universities. Youth league organizations in colleges and universities should conduct in-depth research on the influence of new media on young people, establish a multi-level and widely covered guidance and mobilization system featuring the integration of old and new media, online and offline complementation, keep pace with The Times, keep pace with young people, and effectively carry out the ideological guidance work of the communist youth league on the important platform of new media. At present, many fo the latest elements, combined with the students in colleges and universities to establish the communist youth league official WeChat, official weibo, student organizations at all levels WeChat, weibo, APP new media platforms, such as the client has also created a large approvals and peripheral products, innovation of the ideological and cultural products output form, further enrich the spiritual world of young students. The new media of the communist youth league of colleges and universities should pay attention to the management of the public opinion guided by the network while taking advantage of the initiative of the guidance of the youth network public opinion, so as to create a clear cyberspace. 
To do a good job in guiding the communist youth league's thoughts on the Internet, it is necessary to establish a sound ideological management system, expand network channels, innovate carriers of activities, understand the needs of young people and serve their development. At present, the mainstream ideology has been continuously eroded by the network public opinion, which poses a challenge to the ideological guidance of the communist youth league in the new era[3]. For example, with the widespread application of new media, some negative, partial or even reactionary information and information against social morality is wanton spread on the Internet, weakening the youth's ideological and moral consciousness, affect the youth the objective judgment of information, lead to mainstream public opinion is facing serious challenges, disrupted the college students' learning life rule, makes it easy to depression, physical and mental health greatly affected.

\section{STRATEGIES FOR IDEOLOGICAL AND POLITICAL GUIDANCE OF THE COMMUNIST YOUTH LEAGUE IN COLLEGES AND UNIVERSITIES}

\subsection{Focusing on The Spiritual Growth Needs of Young Students, Constantly Activate the Ideological and Political Leading Function of the Communist Youth League in Colleges and Universities}

When conducting ideological and political guidance among young students, the communist youth league of colleges and universities should not only adhere to the theme of learning xi jinping thought on socialism with Chinese characteristics for a new era, cultivating and practicing socialist core values, but also think and plan from the spiritual needs of young students, so as to organically combine the two. For example, we should use the methods and methods that students are willing to accept to make specific and thorough explanations of the relevant party line and policies. Using the theory of career planning for college students, further guide college students to establish correct and reasonable life goals; Through college students quality development and other methods to help students integrate into the class, the dormitory; By understanding the social hot spots that students are concerned about, inviting party and government experts to hold the current politics report meeting, designing new media boutique projects, etc., students can be effectively guided. The grassroots youth league branch in colleges and universities should start from the specific needs of students, analyze the common problems and topics of concern, and carry out discussions in the form of class meetings and symposiums, so as to form a resonance in the discussion, so as to achieve a better effect of ideological and political guidance.

\subsection{Focusing on the Fundamental Responsibility of The Training Carrier of "the Young Marxist Project", Constantly Exert the Leading Force and Radiation Force of the Backbone of Young Students}

In 2007, the central committee of the communist youth league (cyl) proposed to implement the "The Young Marxist Project", which is divided into three levels: national, provincial and university. It aims to train the backbone of college students, bring the majority of young students to rally around the party, and strengthen the belief of the majority of young students to follow the party. "The Young Marxist Project" has become one of the important work brands for the communist youth league of colleges and universities to integrate into the "Big Ideological And Political" work pattern. The essence of the " The Young Marxist Project" is to train the party's politically competent young people, which is an important duty of the communist youth league as the party's assistant. At present, China has entered an important stage of reform and development, and people are confronted with the impact of various complicated thoughts. On the other hand, foreign hostile forces have been taking various means to increase the ideological penetration of our country, especially the struggle for the ideological consciousness of college students. Therefore, how to better carry out the"The Young Marxist Project" in colleges and universities is particularly important[4].

The educators in colleges and universities want to work at the "Big Ideological And Political" pattern plays a role, attaches great importance to the implementation of " The Young Marxist Project", in completes the routine work of thinning innovation at the same time, further completes the overall design, with the help of "The Young Marxist Project" research and training base of resources, giving full play to the advantages of" The Young Marxist Project" teacher or mentor, research, summarizes the youth political cadre training, targeted training courses and training path design, and distribute the corresponding learning materials Colleges and universities can establish the training pattern of "school-school-league committee-college league committee", build an information platform, and realize resource sharing through special websites and WeChat public accounts. The youth league organizations in colleges and universities should give full play to the leading role of the backbone of college students and lead more students to firm up their ideals and beliefs, so as to achieve the best effect of" The Young Marxist Project" in educating students. 


\subsection{Focus on the Close Connection Between New Media and Young Students, and Constantly Innovate the Way of Leading Work With Online Ideas}

The communist youth league of colleges and universities is the main force to play the role of new media. Therefore, the communist youth league of colleges and universities can carry out the reform from the following four aspects in the innovation and online thought leading work. The first is to create quality activities. Grasp the characteristics of young students' behavioral awareness, fully mobilize their enthusiasm and creativity, plan and launch a series of brand activities with large audience, wide dissemination and deep influence; Combined with the background of The Times, give play to the advantages of the communist youth league as "the voice of the party" to build the brand activities of the communist youth league; We should make full use of professional platforms, strengthen communication and cooperation with foreign media, seize the audiences of various publicity channels, and give full play to the ideological guidance of the communist youth league. Second, broaden the channels of publicity. Give full play to the propaganda of the traditional media and new media features, explore publicity channels, emphasizing both publications, radio and other traditional media publicity, publicity window, and to use new media such as WeiBo, WeChat timeliness is strong, the advantage of disseminated widely, the students gathered positions increase the propaganda work, efforts to promote the influence for the communist youth league in young students. Third, focus on content optimization. Adhere to the "content first", improve the quality and level of idealed content, enhance the attractiveness of content, grasp the timeliness of communication, enhance the depth and breadth of communication[5]. Fourth, establish a crisis intervention mechanism. We should further improve the mechanism of idea-led crisis response, enhance the ideological awareness of young students, and give full play to the role of the emergency mechanism in case of emergencies or mass incidents, so as to improve the public relations ability to cope with crises.

\subsection{Focus on the Needs of Young Students at Different Levels, and Constantly Implement More Precise and Precise Thought Guidance}

The ideological and political guidance work of the communist youth league in colleges and universities must recognize the differences in the growth process of young students, stratify and classify the ideological and political guidance of college students, teach them according to their aptitude, and differentiate and respond to each other to form the resultant force of overall optimization. The ideological and political guidance of the communist youth league in colleges and universities should focus on the following three aspects. First, the content should be differentiated. Facing undergraduate and graduate students, new students and graduates, the goal, content and method of ideological and political guidance should be different. Second, the object should be clear. Different ideological education contents should cover different group objects. For example, "The Young Marxist Project" should be implemented in colleges and universities, and its training objects should be targeted at young students who are interested in the theory of the party and the communist party of China (CPC) and the current political hot spots. Third, we need high efficiency. In the new media era, network information changes frequently and quickly, and the focus of young students' changes rapidly. If colleges and universities fail to grasp the problems that students pay attention to in time and the service process fails to keep pace, ideological and political education will be difficult to achieve good results.

\section{CONCLUSION}

In order to do a good job in guiding the ideological and political work of the communist youth league in the new era, colleges should systematically think about the spiritual growth needs of young students, the fundamental responsibility of the training carrier of "The Young Marxist Project", the close relationship between new media and young students, and the needs of young students at different levels. Colleges should build an integrated work system of stratification and classification, and guide young students with effective ideology, politics and values, so as to give full play to the important role of the communist youth league in the work pattern of " Big Ideological And Political ".

\section{REFERENCES}

[1] Edited by literature research office of the CPC central committee, Edited by Xi Jinping on youth and the work of the communist youth league, Beijing: central literature press, 2017.

[2] Notice of the central ministry of education of the communist youth league on the issuance of the reform implementation plan of the communist youth league of colleges and universities, DOI: http://www. moe.edu.cn/jyb_xxgk/moe_1777 / moe_1779/201703 / t20170320_300172.html.

[3] The ministry of education of the central committee of the communist youth league issued the opinions on strengthening and improving the ideological and political work of the communist youth league in colleges and universities under the new situation, DOI: http://edu. people. com. cn/n1/2017/0606/c105329319652.html. 
[4] Liu Jia, Research on the basic problem of ideological guidance of communist youth league in colleges and universities, Journal of Guangdong youth vocational college, 2016.

[5] $\mathrm{Xi}$ Jinping attended the national conference on ideological and political work of colleges and universities and delivered an important speech, DOI: http://www.

gov.cn/xinwen/2016-

12/08/content_5145253. htm\#1. 